\title{
Impact of Nutritional Epigenetics in Essential Hypertension: Targeting microRNAs in the Gut-Liver Axis
}

\author{
Rachel M. Golonka ${ }^{1} \cdot$ Johnathan Kawika Cooper ${ }^{2} \cdot$ Rochell Issa $^{2} \cdot$ Pratyush Pavan Devarasetty $^{2} \cdot$ Veda Gokula $^{2}$. \\ Joshua Busken ${ }^{2} \cdot$ Jasenka Zubcevic $^{1,3}$. Jennifer Hill ${ }^{1} \cdot$ Matam Vijay-Kumar $^{1} \cdot$ Bindu Menon $^{4} \cdot$ Bina Joe $^{1}$ (iD
}

Accepted: 25 March 2021 / Published online: 7 May 2021

(C) The Author(s) 2021

\begin{abstract}
Purpose of Review To review the current knowledge on interactions between dietary factors and microRNAs (miRNAs) in essential hypertension $(\mathrm{EH})$ pathogenesis.

Recent Findings There exists an integration of maintenance signals generated by genetic, epigenetic, immune, and environmental (e.g., dietary) factors that work to sustain balance in the gut-liver axis. It is well established that an imbalance in this complex, intertwined system substantially increases the risk for EH. As such, pertinent research has been taken to decipher how each signal operates in isolation and together in EH progression. Recent literature indicates that both macro- and micronutrients interrupt regulatory miRNA expressions and thus, alter multiple cellular processes that contribute to $\mathrm{EH}$ and its comorbidities. We highlight how carbohydrates, lipids, proteins, salt, and potassium modify miRNA signatures during EH. The disruption in miRNA expression can negatively impact communication systems such as over activating the renin-angiotensin-aldosterone system, modulating the vascular smooth muscle cell phenotype, and promoting angiogenesis to favor EH. We also delineate the prognostic value of miRNAs in EH and discuss the pros and cons of surgical vs dietary prophylactic approaches in EH prevention.

Summary We propose that dietary-dependent perturbation of the miRNA profile is one mechanism within the gut-liver axis that dictates EH development.
\end{abstract}

Keywords Gut microbiome $\cdot$ Vasculature $\cdot$ Renin-angiotensin-aldosterone system $\cdot$ Hyperlipidemia $\cdot$ Bariatric surgery

\section{Introduction}

An appropriate bidirectional crosstalk within the gut-liver axis (GLA) is essential to sustain physiological homeostasis. As summarized in Fig. 1, the liver initiates an enterohepatic relationship by synthesizing and metabolizing a variety of endogenous solid constituents, such as bile salts, bilirubin, phospholipids, and cholesterol [1]. These components are packaged

Johnathan Kawika Cooper, Rochell Issa and Pratyush Pavan Devarasetty contributed equally to this work.

This article is part of the Topical Collection on Prevention of Hypertension: Public Health Challenges

Bindu Menon

bindu.menon@utoledo.edu

Bina Joe

bina.joe@utoledo.edu

1 Microbiome Consortium, Center for Hypertension and Precision Medicine, Department of Physiology and Pharmacology, The University of Toledo College of Medicine and Life Sciences, Block Health Science Bldg, 3000 Arlington Ave, Toledo, OH 43614, USA

2 The University of Toledo College of Medicine and Life Sciences, Toledo, OH, USA

3 Department of Physiological Sciences and Center for Environmental and Human Toxicology, University of Florida Genetics Institute, Interdisciplinary Program in Biomedical Sciences Neuroscience, College of Veterinary Medicine, University of Florida, Gainesville, FL 32611, USA

4 Department of Medical Education, University of Toledo College of Medicine and Life Sciences, Room 3105B, CCE Bldg, 2920 Arlington Ave, Toledo, OH 43614, USA 


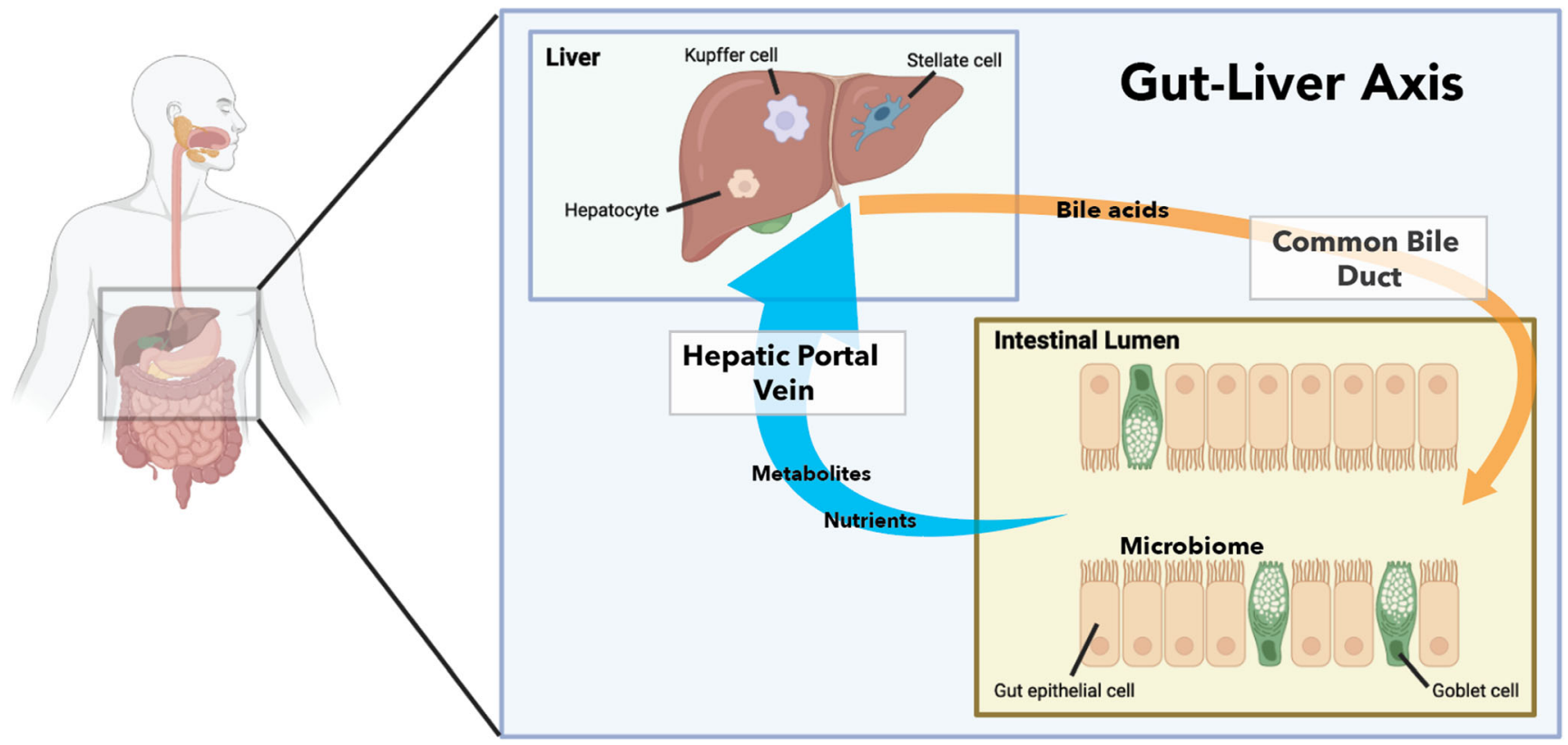

Fig. 1 Bidirectional communication between the gut and the liver is required to maintain physiological homeostasis. The liver supplies bile, which is an aqueous solution of bile acids, bilirubin, organic solutes, and hormones, for nutrient assimilation, immune system stimulation, and intestinal development. The hepatic portal vein transfers venous blood enriched with nutrients and metabolites from the gut to the liver, which instigates xenobiotic metabolism and immune cell activation with water as bile and deposited into the biliary tract for storage in the gallbladder. Upon ingestion of food, the gallbladder is signaled to contract and secrete bile into the small intestine for assimilation of nutrients. Food (e.g., indigestible carbohydrates like dietary fiber) that is not hydrolyzed by host digestive enzymes travels to the large intestine and is catabolized by commensal microorganisms known as the gut microbiota [2]. At the same time, host compounds like bile salts and bilirubin that enter the colon are susceptible to biotransformation into secondary-derived microbial products [3, 4]. This collection of dietary, host-derived, and microbial-derived components is transported via portal vein to the liver, where absorption of such contents can dictate the degree of immune stimulation and thus, inflammatory responses in the liver. For instance, gut-derived products can activate IL-6 production from Kupffer cells (resident macrophages in the liver), which have been suggested to stimulate acute phase protein production from hepatocytes [5]. Importantly, acute phase proteins thereafter impact the gut microbiota to complete the bidirectional communication circle, as we and others have shown that gut microbiota stimulation of lipocalin-2 limits the bioavailability of iron and therefore restricts the growth of iron-dependent pathobionts in the intestine [6-8].

In cases of gut barrier dysfunction, more commonly termed a "leaky gut," excess release of microbial components can serve as ligands for pattern recognition receptors that instigate excessive inflammation and increase the risk for hepatic tissue damage [9]. One of the major responses upon liver injury is the transactivation of hepatic stellate cells into pro-fibrotic myofibroblasts [10, 11]. End-stage fibrosis (i.e., cirrhosis) can obstruct portal vein blood flow, resulting in portal hypertension characterized by intrahepatic vascular resistance and elevated blood pressure [12]. Alongside portal hypertension, our group was one of the first to reveal the link between gut microbiota and salt-sensitive hypertension [13••], where our later studies identify more mechanistic insights to how disruption in the GLA negatively impacts blood pressure [14-16, 17•]. A recent review by Simbrunner et al. elegantly introduces several molecular mechanisms for GLA signaling in portal hypertension, including host-microbiome co-metabolism [18]. Another respective review by Guo et al. describes the therapeutic potential of microRNAs (miRNAs) in regulating hepatic stellate cell differentiation to treat portal hypertension [19・•]. Furthermore, a meta-analysis by Marques et al. characterizes miRNA signatures in the major blood pressure regulatory organs from rodent models and human studies of essential hypertension $[20 \bullet \cdot]$.

Herein, we expand by compiling available evidence on how dietary perturbation in the GLA alters miRNA expressions during essential hypertension (as summarized in Fig. 2). This includes examining the reported effects of macro- and micronutrients, such as carbohydrates, lipids, proteins, salt, and potassium. We also discuss the prognostic and therapeutic value of miRNAs in essential hypertension and outline potential dietary factors that could prove fruitful for prevention and management of essential hypertension via modulation of miRNAs. 


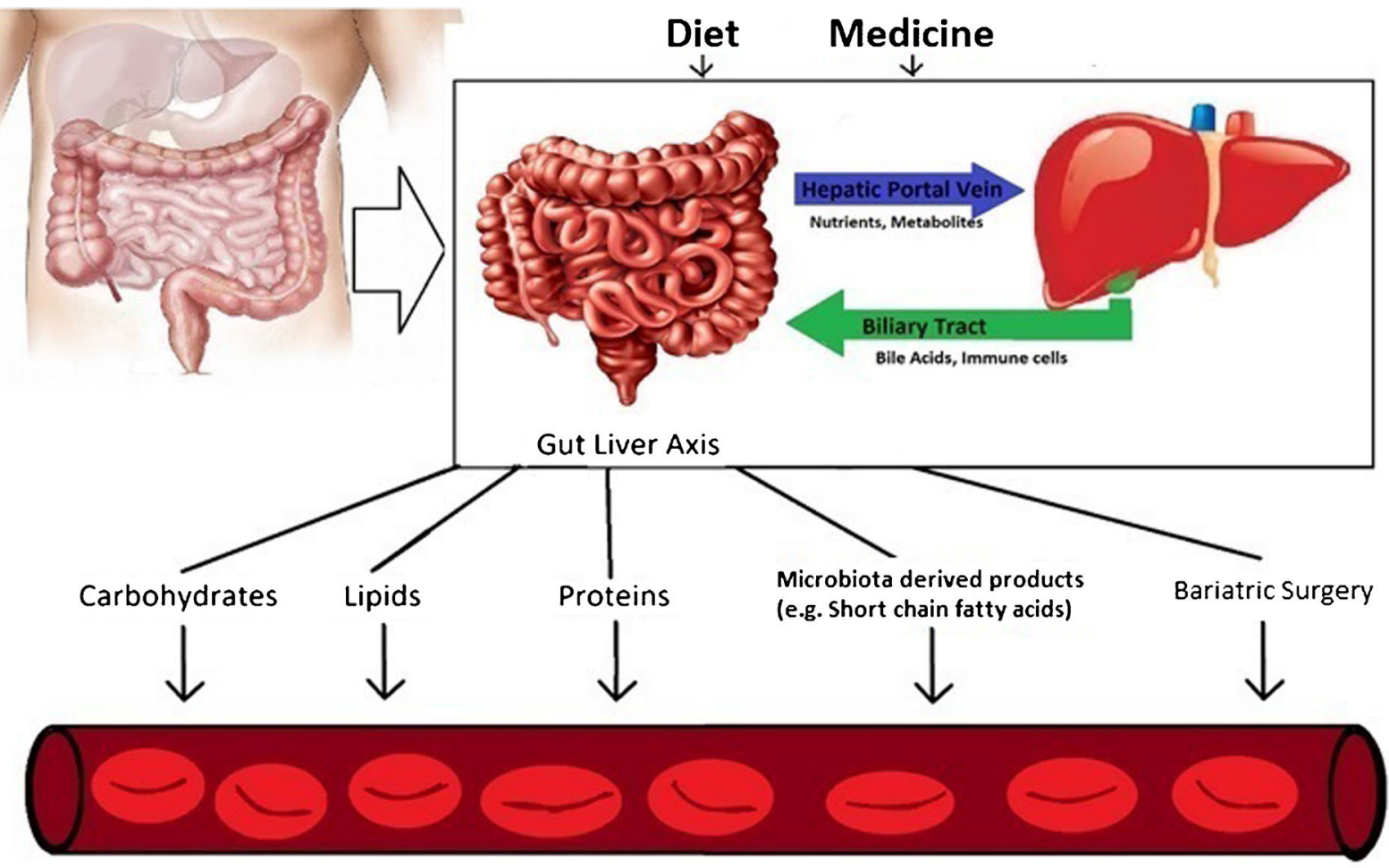

Metabolites in Systemic Circulation

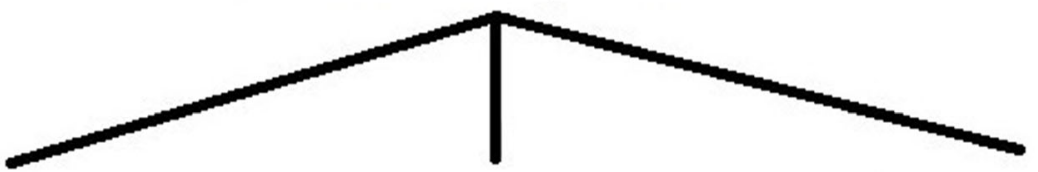

\begin{tabular}{|c|c|}
\hline$\uparrow \operatorname{miR} 221$ & $\uparrow \operatorname{miR} 21$ \\
\hline$\downarrow \operatorname{miR} 145$ & $\downarrow \operatorname{miR} 26 b$ \\
\hline$\downarrow \operatorname{miR} 217$ & $\uparrow \operatorname{miR} 143$ \\
\hline $\operatorname{miR} 21$ & $\downarrow \operatorname{miR} 145$ \\
\hline$\uparrow \operatorname{miR} 222$ & $\downarrow \operatorname{miR} 217$ \\
\hline$\downarrow \operatorname{miR} 26 b$ & $\begin{array}{l}\uparrow \operatorname{miR} 221 \\
\uparrow \operatorname{miR} 22 ?\end{array}$ \\
\hline
\end{tabular}

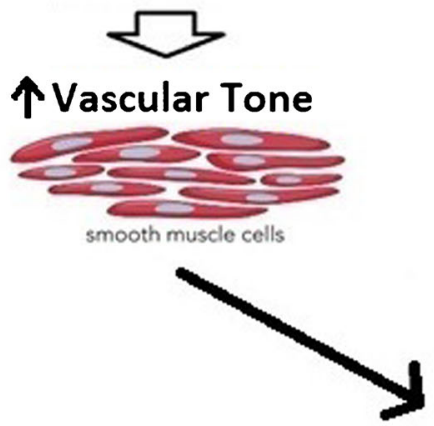

个 $\operatorname{miR} 27 b$

$\downarrow \operatorname{miR} 126$

$\uparrow \operatorname{miR} 122$
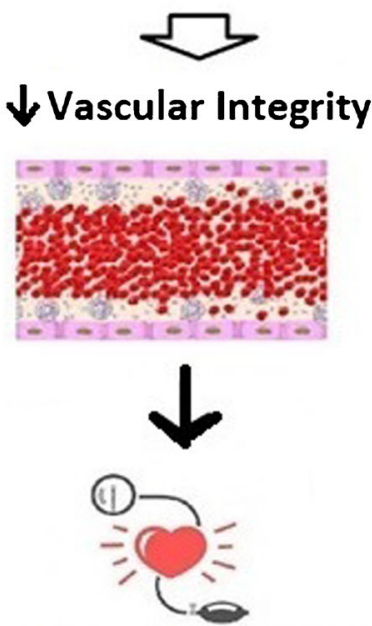

$\uparrow \operatorname{miR} 27 a$

$\uparrow$ miR 27b

$\downarrow \operatorname{miR} 29 \mathrm{~b}$

$\downarrow \operatorname{miR} 155$

个 miR 192

$\uparrow \operatorname{miR} 200 a$

$\uparrow \operatorname{miR} 200 \mathrm{~b}$

$\downarrow \operatorname{miR} 429$
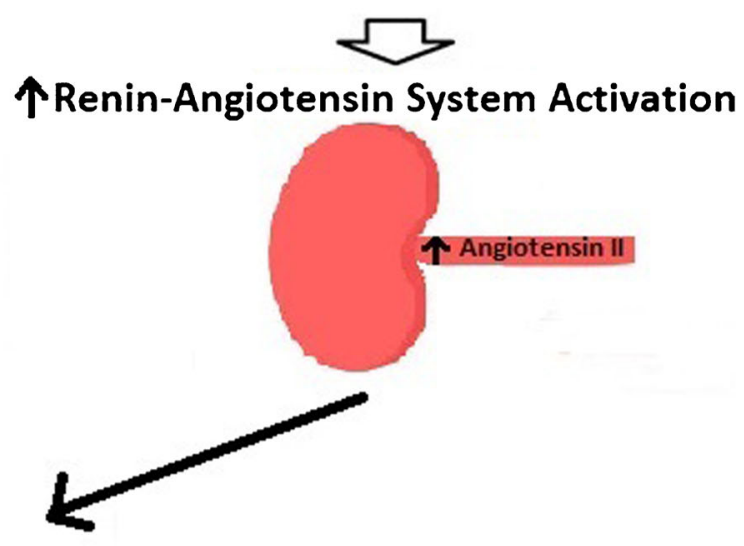

ESSENTIAL HYPERTESION

Fig. 2 Altered miRNA expressions within the gut-liver axis from response to diet promote essential hypertension. Dietary components such as carbohydrates, lipids, and proteins can alter the miRNA signatures that favor for increased vascular tone and renin-angiotensinaldosterone system activation, but reduced vascular integrity, which all collectively contribute to essential hypertension development. In addition, therapeutic approaches such as probiotics to increase short chain fatty acid levels and/or bariatric surgery can affect miRNAdependent regulation of vascular function and thus, increase risk for essential hypertension 


\section{microRNAs in the Gut-Liver Axis}

miRNAs are single-stranded, non-coding RNAs approximately 21-25 nucleotides long that are required for nearly all cellular processes related to animal and plant development [21]. Processing from immature to mature miRNAs is a two-step system: (i) primary miRNA transcripts are cleaved by the RNase III nuclear enzyme Drosha and (ii) the released stem-loop pre-miRNA is cleaved by the RNase III cytosolic enzyme Dicer to make a mature miRNA $[22,23]$. The mature miRNA then forms an effector RNA-induced silencing complex in collaboration with members of the Argonaute family of proteins to repress protein-coding messenger RNAs via degradation [24]. When considering that miRNAs are predicted to regulate around $30 \%$ of proteinencoding genes [25], it is not surprising that miRNAs have been implicated in a variety of pathophysiological outcomes. It is noteworthy that the miRNA signature is specifically altered in liver diseases and can dictate either pro- or anti-inflammatory, pro- or anti-fibrotic, and oncogenic- or tumor-suppressive gene expressions [26]. Interestingly, miRNAs and the gut microbiota have a reciprocal regulatory interaction on each other in both physiological and pathological conditions [27]. This suggests that miRNAs may be an important GLA component in modulating both liver and gut homeostasis.

In portal hypertension, most research to date has focused on miRNA signatures associated with hepatic cirrhosis and splenomegaly as the causation and secondary consequence, respectively. The impact of miRNAs on hepatic stellate cells and other signaling pathways in cirrhosis has been reviewed in-depth [28-31], whereas the molecular role of miRNAs in hypersplenism has only been recently described. Whole-genome microarray analysis has identified a distinct miRNAome in the enlarged spleens of animals with partial portal vein ligation-induced hypertension, including twenty-two downregulated miRNAs that would normally suppress fibrotic related mRNAs (e.g., Collal, Serpine1) [32•]. Intriguingly, miRNA-615-3p was found to be highly expressed in the splenic macrophages of cirrhosisrelated portal hypertensive patients who underwent splenectomy [33]. Further analysis revealed that excess miRNA-615-3p repressed the ligand-dependent nuclear receptor corepressor, followed by enhanced PPAR $\gamma$ dependent phagocytic capacity from macrophages [34], which delineates one potential cellular mechanism of hypersplenism during portal hypertension. Considering the reported impacts of the miRNA-mRNA network on physiology, we propose that miRNAs may also be responsible for the GLA-dependent mechanisms in essential hypertension $(\mathrm{EH})$.

\section{Prognostic Value of microRNAs in Essential Hypertension}

EH is a complex, multi-factorial, polygenic condition with heterogeneous etiological risk factors. Extensive molecular genetic research has identified single nucleotide polymorphisms in several genes for Mendelian categorized EH [35]. High-salt intake, excessive alcohol, stress, and low potassium consumption have also been pinpointed as dominant environmental contributors to EH pathogenesis [36]. Most recently, epigenetics has emerged as a novel and powerful hallmark of EH progression, which encompasses DNA methylation, posttranslational histone modifications, and miRNAs [37, 38]. By studying epigenetics, the heredity aspects of EH and its phenotypes may be clarified $[39,40]$. In this scenario, the miRNAs are clinically relevant due to their capability to affect several gene expressions.

Importantly, specific miRNAs have been suggested as potential stable circulating biomarkers for EH diagnostic applications. This includes a collection of miRNAs reported to be either upregulated (e.g., miR-1, miR-21, miR-122, miR-198, miR-202-3p, miR-208b, miR-499, miR-505, miR-510, miR575 , miR-1183) [41 •, 42, 43•, 44-50] or downregulated (e.g., miR-9, miR-10a-5p, miR-26b, miR-29a, miR-29b, miR-29c, miR-30e-5p, miR-126, miR-133a, miR-136, miR-143, miR144-3p, miR-145, miR-146a) [43•, 48, 50-55] in circulation of EH patients compared to healthy controls. This miRNA profile is correlated with sub-clinical cardiovascular diseases such as left ventricular hypertrophy, cardiac remodeling, carotid intima-media thickness, nephropathy, albuminuria, endothelial dysfunction, and vascular dysfunction [42, 44-46, $48,51,52,54,56-58]$. In addition, miRNAs are associated with alterations in specific cellular communication systems like renin-angiotensin-aldosterone system, vascular smooth muscle modulation, angiogenesis, and mineral ion binding, which all reportedly contribute to EH pathogenesis [43•, 44, 49-51]. Investigation of EH in rodent and zebrafish models identified miR-27a and miR-27b as additional prohypertensive miRNA candidates, as their increased presence in extracellular vesicles was linked to reduction in endothelial nitric oxide synthase phosphorylation, impaired angiotensin-(1-7)-dependent vasodilation, and increased angiogenesis [59••, 60]. Overall, analyses of the circulating miRNA signatures present a prognostic tool as well as pave the way for precision medicine of $\mathrm{EH}$ patients.

\section{Nutritional Impact on microRNA Signatures in Essential Hypertension}

There exists multiple environmental and genetic factors that can perturb the gut microbiota to cause dysbiosis and aid in the blooming of opportunistic pathogenic bacteria at the expense 
of beneficial commensals [61]. Recent studies highlight a strong association between gut dysbiosis and EH [62] and suggest that the microbiome composition contributes to $\mathrm{EH}$ pathogenesis [63••]. Thus, interventions at the gut microbiota level to normalize blood pressure and vascular function may be beneficial. Guidelines from the American College of Cardiology and American Heart Association suggest dietary lifestyle changes to manage and prevent $\mathrm{EH}$ [64••]. In addition, the emerging field of nutritional epigenetics [65] show that dietary perturbations within the GLA may have downstream effects on miRNA signatures. In this section, we discuss the potential of leveraging nutritional epigenetics for $\mathrm{EH}$ treatment.

\section{Carbohydrates}

It is well recognized that a Western-style diet, composed of excessive simple carbohydrates and saturated fats, is a risk factor for EH development [66]. One ingredient that has received heavy research attention to date is high-fructose corn syrup found in sweetened beverages and Westernized foods. Consumption of dietary fructose alone is sufficient to elevate blood pressure in adolescents and adults [67-69] whereas glucose ingestion does not change blood pressure [69]. As such, fructose has been acknowledged as an independent risk factor for EH progression for humans [70] and rodent hypertensive models [71, 72]. Several studies delineate the role of fructose on sodium and electrolyte balance, nitric oxide (NO) bioavailability, oxidative stress, and vascular integrity [73, 74], which in turn promotes $\mathrm{EH}$.

In view of the evidence, it is plausible that fructose could alter miRNA expression in the GLA during EH. A study by Sud et al. found that a high-fructose diet significantly altered the expression levels of certain miRNAs related to lipid metabolism [75••]. Intriguingly, some of the same miRNAs are associated with regulating endothelial function and blood pressure. For instance, expression levels of miR-19b and miR-101a were suppressed following a high-fructose diet [75••], and this could attribute to $\mathrm{EH}$ pathogenesis considering that both miRNAs demonstrate anti-atherogenic properties [76]. While this evidence suggests miR-101a as anti-hypertensive, this miRNA is reportedly a part of an underlying mechanism of increased diastolic blood pressure from air pollution exposure [77], highlighting the complexity of miRNA function. Overconsumption of fructose also upregulated the expression of miR-145a [75••], a candidate prohypertensive miRNA and potential biomarker for diagnosing $\mathrm{EH}$ as silencing miR-145a in spontaneously hypertensive rats protected against $\mathrm{EH}$ by restoring NO metabolism [78]. These studies collectively suggest that future research should investigate the potential role of fructoseinduced augmentation of miR-145a in EH.
In addition to the reported effects of fructose on miRNAs, other evidence suggests the renin-angiotensin-aldosterone system (RAAS) as an intermediate in fructose-miRNA interaction. As low blood pressure initiates the RAAS cascade to elevate blood volume and arterial tone, the liver is the primary site of angiotensinogen production, a precursor for angiotensin II (Ang II), which acts as a potent vasoconstrictor and promotes sodium and water reabsorption via angiotensin II type I receptor (AT1) in the kidney, adrenal cortex, arterioles, and brain [79]. Interestingly, excessive levels of intra-renal Ang II [80] and increased AT1 signaling [81] have been implicated in the hypertensive effects from high a fructose diet. Moreover, miR-155 functions downstream of Ang II signaling as a negative feedback regulator, a suggested protective mechanism against cardiac hypertrophy [82••]. This posits that the negative regulation of Ang II by miR-155 might be impaired during $\mathrm{EH}$; however, further studies are required to delineate this possibility.

The role of miRNAs in fructose-induced EH may also be mediated via advanced glycation end (AGE) products. Fructose, like other reducing sugars, can nonenzymatically react with free amino groups from proteins, lipids, or nucleic acids through the Maillard reaction (glycation) to produce AGE [83, 84]. It is important to note that glucose is the lesser/slower reactive sugar that participates in glycation when compared to fructose [84]. Associative studies have found that AGE are significantly higher in EH patients [85], as they reportedly contribute to endothelial dysfunction [86]. A study by $\mathrm{Wu}$ et al. demonstrates that AGE can suppress miR-200b and miR-200c, leading to unregulated RhoA/ROCK2 signaling during endothelial injury [87]; however, whether this relates to $\mathrm{EH}$ etiology remains unknown. Thus, the role of elevated AGE [88] and/or impaired endothelial mechanotransduction [89] as a result of dietary sugar consumption needs further investigation in EH. Noteworthy is that chronic ingestion of sucrose reportedly increased circulatory miR-21 and miR-223 [90]. Therefore, this miRNA change may be a compensatory response when considering that (i) $\mathrm{EH}$ patients have elevated levels of miR-21 in circulation, (ii) delivery of miR-21 lowered blood pressure in spontaneously hypertensive rats via restoration of mitochondrial function, and (iii) miR-223 is anti-atherogenic by targeting $\beta 1$ integrin [91•, 92]. Overall, future studies should directly explore whether perturbation of the GLA by fructose and/or sucrose changes the miRNA profile to favor $\mathrm{EH}$.

\section{Lipids and Fatty Acids}

Adoption of a sedentary lifestyle and dietary changes (i.e., excessive intake of lipids) that lead to a positive energy balance can cause hyperlipidemia. In addition to lipid 
overconsumption, which leads to hyperlipidemia, as a risk factor for EH progression [93], there exists is a coupling effect for dietary fats to aggravate developed EH [94]. Impressively, mothers consuming high-fat diet (HFD) during the perinatal period increases the probability for offspring to exhibit fetal reprogramming toward EH development [95]. Alterations in the gut microbiota and their metabolite profile [95] have been suggested to contribute to the intergenerational transfer of $\mathrm{EH}$ risk, and this may reflect the changes in miRNA composition. For one, prolonged maternal exposure to HFD was associated with downregulation of miRNA processing in the offspring, which contributed to fetal cardiac hypertrophy [96・• ]. Additionally, a recent study by MantillaEscalante et al. finds that postprandial lipemia causes specific miRNA responses including tissue enrichment of miR-206-3p, miR-543-3p, miR-466c-5p, miR-27b-5p, miR-409-3p, miR-340-3p, miR-1941-3p, miR-10a-3p, miR-125a-3p, and miR-468-3p [97•]. Analyses of circulating miRNA profiles in $\mathrm{EH}$ associated with hyperlipidemia conditions show an increase for miR-21, -146a, $221,-143,-34 a$, and miR-204 in plasma levels, elevated miR-126, -146a, -223, -222, and miR-214 and reduced miR-143, miR-10a, and miR-145 in platelets, and increased miR-222, -221, -210, and miR-34a and decreased miR-223, -214, -146a, -143, -10a, and miR-145 in platelet derived vesicles [98]. Thus, it could be theorized that the vascular hyperreactivity and cardiac remodeling during $\mathrm{EH}$ is due to hyperlipidemia-dependent changes in miRNA expressions, such as downregulation of miR10a, miR-139b, miR-206, and miR-222 and/or upregulation of hsa-miR-223-3p, hsa-miR-21-5p, and hsa-miR$146 a-5 p[99,100 \bullet \bullet$. Furthermore, miR-21 is upregulated in enriched lipid environments and disrupts the remodeling of vascular smooth muscle cells during EH [50].

There are four types of fatty acids: saturated, monosaturated, polyunsaturated, and trans-fat. Comparatively, saturated, monounsaturated, and transfats, but not polyunsaturated fatty acids (e.g., $\omega 3$ and $\omega 6)$, are associated to EH [101]. In line with this, HFDfed rats that consumed linoleic acid ( $\omega 6)$ were found to have lower miR-27a (pro-hypertensive candidate) and restoration of miR-143 (normally blunt in EH) [102], suggesting that polyunsaturated fatty acids could be therapeutic against hyperlipidemia-associated EH. Accordingly, much research has focused on understanding the role of saturated fatty acids in EH progression because it is the most consumed form of dietary lipids. Palmitic acid, in particular, has received much attention for obesity-associated EH by upregulating endothelin-1 levels through induction of endoplasmic reticulum stress [103]. Multiple mechanisms may exist via which saturated fatty acids influence $\mathrm{EH}$, including damaging the integrity of the inner lining of blood vessels in the vascular endothelium, diminishing NO production, increasing oxidative stress, exacerbating inflammation, and promoting the activation of RAAS [104]. It is noteworthy that postprandial lipemia resulting from ingestion of enriched saturated fatty acids-mostly composed of palmitic acid-downregulated miR-300 and miR-369$3 p$ but upregulated miR-495-3p, miR-129-5p, and miR$7-2-3 p$ in peripheral blood mononuclear cells [105]. This connection among lipemia, miRNA, and EH is evident but requires additional mechanistic studies to confirm how these changes in miRNA levels impact EH etiology and progression.

\section{Proteins and Amino Acids}

Dietary Approaches to Stop Hypertension (DASH) studies [106] indicate that long-term intake of a high-protein diet, at the expense of carbohydrates, from either animal or plant sources has protective benefits to lower the risk of EH [107] and to maintain reduced blood pressure even after weight loss [108]. While no studies have currently looked at the direct effects of protein on miRNA expression in $\mathrm{EH}$, evidence indicates that certain amino acid intermediates may play a role in EH pathology. For instance, homocysteine and asymmetrical dimethylarginine (ADMA) are two byproducts from post-translational modification (i.e., methylation) of arginine [109]. Metabolism of methionine is another source for homocysteine [110]. Hyperhomocysteinemia (serum homocysteine levels $>10$ $\mu \mathrm{mol} / \mathrm{L})[111,112]$ and significantly increased ADMA levels [113] have become more widely recognized as risk factors for $\mathrm{EH}$ development. ADMA is primarily known to inhibit NO bioavailability and induce endothelial dysfunction [113], whereas homocysteine can also inhibit NO synthesis while promoting oxidative stress. Recently, Li et al. found that homocysteine can competitively inhibit Ang II when activating AT1 in the RAAS pathway [114••]. Homocysteine is also well known for stimulating proliferation of vascular smooth muscle cells [115], reportedly via miR-143 hypermethylation [116] and blunted miR-145/CD40 [117, 118] but this can be abated by (i) miR-217 suppression of the N-methyl-D-aspartic acid receptor [119], (ii) miR-217 promotion of senescence [120], or (iii) miR-145 repression of PI3K/Akt/mTOR signaling $[121 \bullet \bullet]$. Furthermore, cardiac remodeling from homocysteine is linked to the differential expression of 11 miRNAs with miR-188 showing dramatic downregulation in HHcy cardiomyocytes [122]. Despite the reports that homocysteine is related to the phenotypical switches found in EH and that these changes are associated with specific miRNA signatures, these observations need to be confirmed in EH rodent models. 


\section{Micronutrients}

There are five main micronutrients that are known to regulate blood pressure: sodium, chloride, calcium, potassium, and magnesium [123]. Accordingly, the molecular compound sodium chloride has been heavily investigated in EH pathogenesis [124]. Mechanistically, high salt intake has been shown as pathological in EH by regulating immune responses [125], causing renal dysfunction [126], and modulating the gut microbiota and metabolic profile [127]. This also includes dysregulated sodium and water reabsorption, higher glomerular filtration rate, and increase of protein catabolism in EH patients [128]. In line with this, mice deficient in the sodium chloride cotransporter have increased blood pressure when fed a diet with high salt and low potassium [129].

High-throughput miRNA sequencing technology has identified 9 miRNAs suitable as biomarkers for salt-sensitive EH in humans, including upregulation of hsa-miR-15b-5p, hsamiR-362-5p, and hsa-miR-361-5p, but downregulation of hsa-miR-19a-3p, hsa-miR-210-3p, hsa-miR-26b-3p, hsamiR-382-5p, and hsa-miR-423-5p [130]. miRNA libraries have also been created for Dahl salt-sensitive and Lewis rats administered with either normal or high-salt diets, as Naraba and Iwai confirmed 91 previously reported miRNAs and uncovered 12 new miRNAs expressed in the kidney [131]. Interestingly, miR-429 is reportedly necessary for HIF- $1 \alpha-$ mediated sodium excretion in response to high salt intake, whereas deficiency in this miRNA aggravated salt-sensitive EH [132]. In line with this, a recent study by Lu et al. finds that the circular RNA, termed circNrlh4, regulates fatty acid reductase 1 by sponging miR-155-5p, which contributes to renal injury during deoxycorticosterone acetate-salt hypertension [133]. Comparatively, miR-29b is indicated as potentially beneficial against renal fibrosis in salt-induced EH as it suppresses a wide array of genes that encode collagen [134]. Of note is that administration of a first generation $\beta 1$-selective blocker (i.e., nebivolol, atenolol) substantially alleviated cardiac remodeling, hypertrophy, and fibrosis in salt-sensitive EH by attenuating miR-27a and miR-29a [135].

\section{Surgical vs Dietary Prophylactic Approaches to Prevent Essential Hypertension}

\section{Bariatric Surgery}

In association with hyperlipidemia, obesity is a prominent risk factor for EH [136]. Therapeutic approaches have included the coupling of a calorie deficit diet and intense exercise, but recent evidence suggests that surgical procedures such as bariatric bypass, adjustable gastric banding, vertical banded gastroplasty, and biliopancreatic diversion are more successful in maintenance of long-term weight loss and as such, lower the incidence of EH [137]. Sleeve gastrectomy and Roux-en$\mathrm{Y}$ gastric bypass are the two most common types of bariatric surgeries that involve a partial resection of the stomach, which alters bile flow and metabolic pathways to stimulate weight loss in patients with a body mass index greater than 40 [138]. Interestingly, changes in the systemic profile of regulatory miRNAs have been noted by a marked decrease of circulating miR-140-5p, miR-122, miR-193a-5p, and miR-16-1 but an increase of miR-221 and miR-199a-3p following surgeryinduced weight loss [139]. Urinary levels of miR-192, miR$200 \mathrm{a}$, and miR-200b were also found to be upregulated following bariatric surgery [140]. Additionally, liver-specific miR-122, miR-885-5-p, and miR-192 were reduced to levels found in non-obese patients 3 months post-surgery [141]. Changes in the miRNA profile also corresponded with the suppression of pro-inflammatory genes in adipose tissue [142], which could attribute to how miRNAs switch toward an anti-inflammatory metabolic state after gastric bypass.

A recent meta-analysis further affirms that bariatric surgery significantly alters miRNA expressions: (i) downregulated hsa-miR-93-5p, hsa-miR-106b-5p, hsa-let-7b-5p, hsa-let-7i5p, hsa-miR-16-5p, hsa-miR-19b-3p, hsa-miR-92a-3p, hsamiR-222-3p, hsa-miR-142-3p, hsa-miR-140-5p, hsa-miR$155-5 \mathrm{p}$, and rno-miR-320-3p, but (ii) upregulated hsa-miR$7-5 \mathrm{p}$ and hsa-miR-320c [143•]. Since miRNAs were positively correlated with reduced body mass index, percentage fat mass, blood glucose levels, and liver transaminases, these results have instigated the miRNAome as a potential diagnostic tool to indicate the success of bariatric surgery [144]. Considering the drastic weight loss experienced by patients after bariatric surgery, the high rates of EH remission 1 year after surgery are surprising [145]. However, a recent longitudinal genome-wide methylation study revealed that Roux-en$\mathrm{Y}$ gastric bypass patients obtain novel $\mathrm{CpG}$ sites associated with dysregulation of systolic blood pressure, which has provided a plausible epigenetic mechanism to EH post-surgical treatment [146]. Future studies are necessary to delineate if the above changes in the miRNAome could be also contributing to the EH remission observed after bariatric surgery.

\section{Probiotics and Prebiotics: Targeting the Gut Microbiota}

Novel dietary supplements are currently explored to implement either in the pre-hypertensive stage or as co-adjuvants with standard treatment plans for EH. When determining appropriate dietary therapeutics, it is important to note which metabolites are generated once the food is digested by the gut microbiota. In the proximal colon, for instance, saccharolytic (i.e., carbohydrate) fermentation by microbes can generate beneficial short chain fatty acids (SCFA) and vitamins B and K [147, 148]. Comparatively, proteolytic (i.e., amino acid) fermentation in the distal colon can generate 
branch-chain fatty acids but also some potentially detrimental metabolites such as ammonia and phenols [147, 148]. As such, one of the major mainstream options in EH management is the incorporation of either probiotics or prebiotics [149-152, 153•] into the diet to boost saccharolytic fermentation from beneficial commensal microbes and thus generate SCFA like acetate, butyrate, and propionate. This rationale is further supported by the clinical observations that EH patients have greater excretion and less absorption of SCFA [154••, 155, 156].

Dietary supplementation with probiotics may include commensal strains from Lactobacillus and Bifidobacteria whereas prebiotics encompass ingestion of dietary fibers as a nutritional source for the resident gut commensals. The blood pressure regulatory role of SCFA has been delineated in-depth with back-to-back reviews from Dr. Jennifer Pluznick [157, 158]. To summarize, administration of one type of SCFA or as a cocktail mixture has been found to reduce blood pressure by (i) activating olfactory G-protein coupled receptors in the kidney $[159,160]$ and (ii) acting as a histone deacetylase inhibitor [161]. Even though SCFA possess well-established epigenetic effects via inhibiting histone deacetylase function, only one article to date makes a connection between SCFA and miRNA in $\mathrm{EH}$, as Weber et al. note that the miRNA-dependent hypertensive phenotype may be due to its regulation of SCFA receptors in the kidney, which can be normalized by hydrogen sulfide administration [162]. Future studies should aim to further understand the SCFA-miRNA-EH axis.

\section{Conclusion and Future Direction}

This review highlights our current understanding of how miRNAs may influence EH progression in the context of the GLA. Specifically, we delved into the interplay between dietary factors and gut microbiota metabolites in the "turning on" vs "turning off" expression of certain miRNAs, which may dictate a pro-hypertensive vs normotensive state. Noting that our review is one of the first to make the connection among dietary factors, GLA-derived metabolites, and miRNAs in $\mathrm{EH}$, additional research is needed to validate these correlations. The diagnostic value of miRNA in EH has been substantiated, but mechanistic studies are needed to identify the targeted miRNA for precision medicine in EH. Intriguingly, the study by Teng et al. demonstrates that miRNAs from exosome-like nanoparticles in ginger can positively affect the composition of gut microbiome and its metabolites [163], but whether this could be translated to alleviate EH has not yet been explored. Our review indicates that studying the differences between a Westernized style diet vs plantbased diet could provide prevention and/or treatment of EH. Other research also indicates that a Mediterranean diet may provide a beneficial alteration of the miRNA signatures and lower endothelial dysfunction [164]. We acknowledge that miRNAs may be one of many epigenetic factors contributing to EH and further research should determine if other nonregulatory RNAs, such as small and long regulatory RNAs or cyclic RNAs, may have similar implications as miRNAs in EH pathogenesis.

Abbreviations $\omega 3$, omega- $3 ; \omega 6$, omega- $6 ; A D M A$, asymmetrical dimethylarginine; $A G E$, advanced end product; $A K T$, protein kinase $\mathrm{B}$; Ang I, angiotensin I; Ang II, angiotensin II; ATl, angiotensin II type I receptor; $D A S H$, Dietary Approaches to Stop Hypertension; $E H$, essential hypertension; $G L A$, gut-liver axis; $H F D$, high-fat diet; $H I F-1 \alpha$, hypoxia inducible factor $1 \alpha$; IL-6, interleukin-6; miRNA, microRNA; mTOR, mechanistic target of rapamycin; NO, nitric oxide; $P I 3 K$, phosphatidylinositol 3-kinases; $P P A R \gamma$, peroxisome proliferator-activated receptor gamma; $R A A S$, renin-angiotensin-aldosterone system; ROCK2, Rho-associated protein kinase 2; RHOA, Ras homolog gene family, member A; SCFA, short-chain fatty acid

Author Contribution RG, JC, RI, PD, VG, and JB performed the literature search and data analysis. RG drafted and finalized the manuscript. JC and $\mathrm{VG}$ created the figures. JZ, JH, MVK, BM, and BJ critically revised the work. BM and BJ approved the final manuscript.

Funding This work was supported by grants from the NIH to BJ (HL1430820), MVK (CA219144), and JZ (AT010192, HL152162).

\section{Declarations}

Human and Animal Rights and Informed Consent This article does not contain any studies with human or animal subjects performed by any of the authors.

Conflict of Interest The authors declare no competing interests.

Open Access This article is licensed under a Creative Commons Attribution 4.0 International License, which permits use, sharing, adaptation, distribution and reproduction in any medium or format, as long as you give appropriate credit to the original author(s) and the source, provide a link to the Creative Commons licence, and indicate if changes were made. The images or other third party material in this article are included in the article's Creative Commons licence, unless indicated otherwise in a credit line to the material. If material is not included in the article's Creative Commons licence and your intended use is not permitted by statutory regulation or exceeds the permitted use, you will need to obtain permission directly from the copyright holder. To view a copy of this licence, visit http://creativecommons.org/licenses/by/4.0/.

\section{References}

Papers of particular interest, published recently, have been highlighted as:

- Of importance

•- Of major importance

1. Boyer JL. Bile formation and secretion. Compr Physiol. 2013;3(3):1035-78. https://doi.org/10.1002/cphy.c120027. 
2. Myhrstad MCW, Tunsjo H, Charnock C, Telle-Hansen VH. Dietary fiber, gut microbiota, and metabolic regulation-current status in human randomized trials. Nutrients. 2020;12(3). https:// doi.org/10.3390/nu12030859.

3. Hamoud AR, Weaver L, Stec DE, Hinds TD Jr. Bilirubin in the liver-gut signaling axis. Trends Endocrinol Metab. 2018;29(3): 140-50. https://doi.org/10.1016/j.tem.2018.01.002.

4. Jia W, Xie G, Jia W. Bile acid-microbiota crosstalk in gastrointestinal inflammation and carcinogenesis. Nat Rev Gastroenterol Hepatol. 2018;15(2):111-28. https://doi.org/10.1038/nrgastro.2017.119.

5. Norris CA, He M, Kang LI, Ding MQ, Radder JE, Haynes MM, et al. Synthesis of IL-6 by hepatocytes is a normal response to common hepatic stimuli. PLoS One. 2014;9(4):e96053. https:// doi.org/10.1371/journal.pone.0096053.

6. Lim D, Kim HK, Jeong JH, Jung YS, Lee SE, Jang HC, et al. Lipocalin2 induced by bacterial flagellin protects mice against cyclophosphamide mediated neutropenic sepsis. Microorganisms. 2020;8(5). https://doi.org/10.3390/ microorganisms 8050646.

7. Guo BX, Wang QQ, Li JH, Gan ZS, Zhang XF, Wang YZ, et al. Lipocalin 2 regulates intestine bacterial survival by interplaying with siderophore in a weaned piglet model of Escherichia coli infection. Oncotarget. 2017;8(39):65386-96. https://doi.org/10. 18632/oncotarget. 18528.

8. Singh V, Yeoh BS, Chassaing B, Zhang B, Saha P, Xiao X, et al. Microbiota-inducible innate immune, siderophore binding protein lipocalin 2 is critical for intestinal homeostasis. Cell Mol Gastroenterol Hepatol. 2016;2(4):482-98 e6. https://doi.org/10. 1016/j.jcmgh.2016.03.007.

9. Seki E, Schnabl B. Role of innate immunity and the microbiota in liver fibrosis: crosstalk between the liver and gut. J Physiol. 2012;590(3):447-58. https://doi.org/10.1113/jphysiol.2011. 219691.

10. Tsuchida T, Friedman SL. Mechanisms of hepatic stellate cell activation. Nat Rev Gastroenterol Hepatol. 2017;14(7):397-411. https://doi.org/10.1038/nrgastro.2017.38.

11. Iwaisako K, Jiang C, Zhang M, Cong M, Moore-Morris TJ, Park TJ, et al. Origin of myofibroblasts in the fibrotic liver in mice. Proc Natl Acad Sci U S A. 2014;111(32):E3297-305. https://doi.org/ 10.1073/pnas.1400062111

12. Iwakiri Y. Pathophysiology of portal hypertension. Clin Liver Dis. 2014;18(2):281-91. https://doi.org/10.1016/j.cld.2013.12.001.

13.• Mell B, Jala VR, Mathew AV, Byun J, Waghulde H, Zhang Y, et al. Evidence for a link between gut microbiota and hypertension in the Dahl rat. Physiol Genomics. 2015;47(6):187-97. https://doi. org/10.1152/physiolgenomics.00136.2014 This study provided the first link between gut microbiota dysbiosis and saltsensitive hypertension in a genetic rat model. Instigated studies to explore the interplay between host genome and microbiome in blood pressure.

14. Chakraborty S, Mandal J, Yang T, Cheng X, Yeo JY, McCarthy CG, et al. Metabolites and hypertension: insights into hypertension as a metabolic disorder: 2019 Harriet Dustan Award. Hypertension. 2020;75(6):1386-96. https://doi.org/10.1161/ HYPERTENSIONAHA.120.13896.

15. Galla S, Chakraborty S, Cheng X, Yeo JY, Mell B, Chiu N, et al. Exposure to amoxicillin in early life is associated with changes in gut microbiota and reduction in blood pressure: findings from a study on rat dams and offspring. J Am Heart Assoc. 2020;9(2): e014373. https://doi.org/10.1161/JAHA.119.014373.

16. Sherman SB, Sarsour N, Salehi M, Schroering A, Mell B, Joe B, et al. Prenatal androgen exposure causes hypertension and gut microbiota dysbiosis. Gut Microbes. 2018;9(5):400-21. https:// doi.org/10.1080/19490976.2018.1441664.

17. Chakraborty S, Galla S, Cheng X, Yeo JY, Mell B, Singh V, et al. Salt-responsive metabolite, beta-hydroxybutyrate, attenuates hypertension. Cell Rep. 2018;25(3):677-89 e4. https://oi.org/ 10.1016/j.celrep.2018.09.058 This study described a novel connection between certain liver metabolites and blood pressure regulation. Suggested that nutritional supplementation to rescue metabolite levels could alleviate hypertension.

18. Simbrunner B, Mandorfer M, Trauner M, Reiberger T. Gut-liver axis signaling in portal hypertension. World J Gastroenterol. 2019;25(39):5897-917. https://doi.org/10.3748/wjg.v25.i39. 5897.

19.• Guo CJ, Pan Q, Xiong H, Qiao YQ, Bian ZL, Zhong W, et al. Therapeutic potential of microRNA: a new target to treat intrahepatic portal hypertension? Biomed Res Int. 2014;2014: 797898. https://doi.org/10.1155/2014/797898 This review was the first to link the behavior of microRNAs in regulating hepatic stellate cell activation, liver fibrosis, and portal hypertension Implicated microRNAs as relevant therapeutic targets in hypertension.

20.• Marques FZ, Charchar FJ. microRNAs in essential hypertension and blood pressure regulation. Adv Exp Med Biol. 2015;888:21535. https://doi.org/10.1007/978-3-319-22671-2 11 This review characterized miRNA signatures in the major blood pressure regulatory organs from rodent models and human studies of essential hypertension. Highlighted specific microRNA mimics or inhibitors have therapeutic potential in regulating blood pressure.

21. Lagos-Quintana M, Rauhut R, Lendeckel W, Tuschl T. Identification of novel genes coding for small expressed RNAs. Science. 2001;294(5543):853-8. https://doi.org/10.1126/science. 1064921.

22. Gregory RI, Yan KP, Amuthan G, Chendrimada T, Doratotaj B, Cooch N, et al. The Microprocessor complex mediates the genesis of microRNAs. Nature. 2004;432(7014):235-40. https://doi.org/ 10.1038/nature03120.

23. Denli AM, Tops BB, Plasterk RH, Ketting RF, Hannon GJ. Processing of primary microRNAs by the Microprocessor complex. Nature. 2004;432(7014):231-5. https://doi.org/10.1038/ nature03049.

24. Chong MM, Zhang G, Cheloufi S, Neubert TA, Hannon GJ, Littman DR. Canonical and alternate functions of the microRNA biogenesis machinery. Genes Dev. 2010;24(17):1951-60. https:// doi.org/10.1101/gad.1953310.

25. Filipowicz W, Bhattacharyya SN, Sonenberg N. Mechanisms of post-transcriptional regulation by microRNAs: are the answers in sight? Nat Rev Genet. 2008;9(2):102-14. https://doi.org/10.1038/ nrg2290.

26. Schueller F, Roy S, Vucur M, Trautwein C, Luedde T, Roderburg C. The role of miRNAs in the pathophysiology of liver diseases and toxicity. Int J Mol Sci. 2018;19(1). https://doi.org/10.3390/ ijms 19010261.

27. Dong J, Tai JW, Lu LF. miRNA-microbiota interaction in gut homeostasis and colorectal cancer. Trends Cancer. 2019;5(11): 666-9. https://doi.org/10.1016/j.trecan.2019.08.003.

28. Zhao Z, Lin CY, Cheng K. siRNA- and miRNA-based therapeutics for liver fibrosis. Transl Res. 2019;214:17-29. https://doi.org/ 10.1016/j.trs1.2019.07.007.

29. Kanda T, Goto T, Hirotsu Y, Moriyama M, Omata M. Molecular mechanisms driving progression of liver cirrhosis towards hepatocellular carcinoma in chronic hepatitis $\mathrm{B}$ and $\mathrm{C}$ infections: a review. Int J Mol Sci. 2019;20(6). https://doi.org/10.3390/ ijms20061358.

30. Shen J, Huang CK, Yu H, Shen B, Zhang Y, Liang Y, et al. The role of exosomes in hepatitis, liver cirrhosis and hepatocellular carcinoma. J Cell Mol Med. 2017;21(5):986-92. https://doi.org/ $10.1111 / \mathrm{jcmm} .12950$. 
31. Zhou WC, Zhang QB, Qiao L. Pathogenesis of liver cirrhosis. World J Gastroenterol. 2014;20(23):7312-24. https://doi.org/10. 3748/wjg.v20.i23.7312.

32. Saruwatari J, Dong C, Utsumi T, Tanaka M, McConnell M, Iwakiri Y. Integrated analysis of microRNA and mRNA expression profiles in splenomegaly induced by non-cirrhotic portal hypertension in rats. Sci Rep. 2018;8(1):17983. https://doi.org/10. 1038/s41598-018-36297-0 This study provided new mechanistic insight into a specific microRNA-mRNA network potentially implicated in portal hypertension-induced splenomegaly. Indicated that the altered microRNA profile was associated with tissue fibrosis and cell proliferation, which could be causing hypersplenism following portal hypertension.

33. Li Z, Zhang S, Huang C, Zhang W, Hu Y, Wei B. MicroRNAome of splenic macrophages in hypersplenism due to portal hypertension in hepatitis B virus-related cirrhosis. Exp Biol Med (Maywood). 2008;233(11):1454-61. https://doi.org/10.3181/ 0711-RM-321.

34. Jiang A, Zhang S, Li Z, Liang R, Ren S, Li J, et al. miR-615-3p promotes the phagocytic capacity of splenic macrophages by targeting ligand-dependent nuclear receptor corepressor in cirrhosis-related portal hypertension. Exp Biol Med (Maywood). 2011;236(6):672-80. https://doi.org/10.1258/ebm.2011.010349.

35. Singh M, Singh AK, Pandey P, Chandra S, Singh KA, Gambhir IS. Molecular genetics of essential hypertension. Clin Exp Hypertens. 2016;38(3):268-77. https://doi.org/10.3109/ 10641963.2015.1116543.

36. Elliott P, Rogers S, Scally G, Beevers DG, Lichtenstein MJ, Keenan G, et al. Sodium, potassium, body mass, alcohol and blood pressure in three United Kingdom centres (the INTERSALT study). Eur J Clin Nutr. 1990;44(9):637-45.

37. Wise IA, Charchar FJ. Epigenetic modifications in essential hypertension. Int J Mol Sci. 2016;17(4):451. https://doi.org/10.3390/ ijms17040451.

38. Arif M, Sadayappan S, Becker RC, Martin LJ, Urbina EM. Epigenetic modification: a regulatory mechanism in essential hypertension. Hypertens Res. 2019;42(8):1099-113. https://doi.org/ 10.1038/s41440-019-0248-0.

39. Kelsey G, Feil R. New insights into establishment and maintenance of DNA methylation imprints in mammals. Philos Trans R Soc Lond Ser B Biol Sci. 2013;368(1609):20110336. https:// doi.org/10.1098/rstb.2011.0336.

40. Kunes J, Kadlecova M, Vaneckova I, Zicha J. Critical developmental periods in the pathogenesis of hypertension. Physiol Res. 2012;61(Suppl 1):S9-17. https://doi.org/10.33549/physiolres. 932364.

41.• Li L, Zhong D, Xie Y, Yang X, Yu Z, Zhang D, et al. Blood microRNA 202-3p associates with the risk of essential hypertension by targeting soluble ST2. Biosci Rep. 2020;40(5). https://doi. org/10.1042/BSR20200378 This article provided rodent and human data that mechanistically describe how microRNA 202-3p exerts protection from essential hypertension. Found that microRNA 202-3p antagonized the soluble ST2 decoy receptor for interleukin-33 that is normally induced by angiotensin II and thus, lowered blood pressure.

42. Zhang HG, Zhang QJ, Li BW, Li LH, Song XH, Xiong CM, et al. The circulating level of miR-122 is a potential risk factor for endothelial dysfunction in young patients with essential hypertension. Hypertens Res. 2020;43(6):511-7. https://doi.org/10.1038/ s41440-020-0405-5.

43. - Ye Y, Yang J, Lv W, Lu Y, Zhang L, Zhang Y, et al. Screening of differentially expressed microRNAs of essential hypertension in Uyghur population. Lipids Health Dis. 2019;18(1):98. https://doi. org/10.1186/s12944-019-1028-1 This study provided a reference set of circulating microRNAs biomarkers associated with essential hypertension.
44. Zhao X, Yi Y, Meng C, Fang N. MiRNA-575 suppresses angiogenesis by targeting Rab5-MEK-ERK pathway in endothelial cells. Biosci Rep. 2019;39(1). https://doi.org/10.1042/ BSR20181218.

45. Huang YQ, Huang C, Li J, Zhang B, Feng YQ. The association of miR-29a with proteinuria in essential hypertension. J Hum Hypertens. 2018;32(11):775-80. https://doi.org/10.1038/s41371018-0097-3.

46. Huang Y, Tang S, Huang C, Chen J, Li J, Cai A, et al. Circulating miRNA29 family expression levels in patients with essential hypertension as potential markers for left ventricular hypertrophy. Clin Exp Hypertens. 2017;39(2):119-25. https://doi.org/10.1080/ 10641963.2016.1226889.

47. Krishnan R, Mani P, Sivakumar P, Gopinath V, Sekar D. Expression and methylation of circulating microRNA-510 in essential hypertension. Hypertens Res. 2017;40(4):361-3. https:// doi.org/10.1038/hr.2016.147.

48. Kontaraki JE, Marketou ME, Parthenakis FI, Maragkoudakis S, Zacharis EA, Petousis S, et al. Hypertrophic and antihypertrophic microRNA levels in peripheral blood mononuclear cells and their relationship to left ventricular hypertrophy in patients with essential hypertension. J Am Soc Hypertens. 2015;9(10):802-10. https://doi.org/10.1016/j.jash.2015.07.013.

49. Yang Q, Jia C, Wang P, Xiong M, Cui J, Li L, et al. MicroRNA505 identified from patients with essential hypertension impairs endothelial cell migration and tube formation. Int J Cardiol. 2014;177(3):925-34. https://doi.org/10.1016/j.ijcard.2014.09. 204.

50. Kontaraki JE, Marketou ME, Zacharis EA, Parthenakis FI, Vardas PE. Differential expression of vascular smooth musclemodulating microRNAs in human peripheral blood mononuclear cells: novel targets in essential hypertension. J Hum Hypertens. 2014;28(8):510-6. https://doi.org/10.1038/jhh.2013.117.

51. Chu HT, Li L, Jia M, Diao LL, Li ZB. Correlation between serum microRNA-136 levels and RAAS biochemical markers in patients with essential hypertension. Eur Rev Med Pharmacol Sci. 2020;24(22):11761-7. https://doi.org/10.26355/eurrev_202011_ 23828.

52. Koval S, Snihurska I, Yushko K, Lytvynova O, Berezin A. Plasma microRNA-133A level in patients with essential arterial hypertension. Georgian Med News. 2019;(290):52-9.

53. Luo Y, Bao X, Zheng S, Gu T, Mao S, Liu S, et al. A potential risk factor of essential hypertension in case-control study: MicroRNAs miR-10a-5p. Clin Exp Hypertens. 2020;42(1):36-42. https://doi. org/10.1080/10641963.2019.1571597.

54. Perez-Hernandez J, Olivares D, Forner MJ, Ortega A, Solaz E, Martinez F, et al. Urinary exosome miR-146a is a potential marker of albuminuria in essential hypertension. J Transl Med. 2018;16(1):228. https://doi.org/10.1186/s12967-018-1604-6.

55. Kontaraki JE, Marketou ME, Zacharis EA, Parthenakis FI, Vardas PE. MicroRNA-9 and microRNA-126 expression levels in patients with essential hypertension: potential markers of targetorgan damage. J Am Soc Hypertens. 2014;8(6):368-75. https:// doi.org/10.1016/j.jash.2014.03.324.

56. Qin S, Zhang C. MicroRNAs in vascular disease. J Cardiovasc Pharmacol. 2011;57(1):8-12. https://doi.org/10.1097/FJC. 0b013e318203759b.

57. Wang K, Long B, Zhou J, Li PF. miR-9 and NFATc3 regulate myocardin in cardiac hypertrophy. J Biol Chem. 2010;285(16): 11903-12. https://doi.org/10.1074/jbc.M109.098004.

58. Fish JE, Santoro MM, Morton SU, Yu S, Yeh RF, Wythe JD, et al. miR-126 regulates angiogenic signaling and vascular integrity. Dev Cell. 2008;15(2):272-84. https://doi.org/10.1016/j.devcel. 2008.07.008

59.• Zou X, Wang J, Chen C, Tan X, Huang Y, Jose PA, et al. Secreted monocyte miR-27a, via mesenteric arterial mas receptor-eNOS 
pathway, causes hypertension. Am J Hypertens. 2020;33(1):3142. https://doi.org/10.1093/ajh/hpz112 This study was the first to describe a plausible microRNA-dependent mechanism for why extracellular vesicles induce hypertension. miR-27a in extracellular vesicles decreased eNOS phosphorylation and impaired Ang-(1-7)-dependent vasodilation, which caused hypertension.

60. Urbich C, Kaluza D, Fromel T, Knau A, Bennewitz K, Boon RA, et al. MicroRNA-27a/b controls endothelial cell repulsion and angiogenesis by targeting semaphorin 6A. Blood. 2012;119(6): 1607-16. https://doi.org/10.1182/blood-2011-08-373886.

61. Natividad JM, Verdu EF. Modulation of intestinal barrier by intestinal microbiota: pathological and therapeutic implications. Pharmacol Res. 2013;69(1):42-51. https://doi.org/10.1016/j. phrs.2012.10.007.

62. Pevsner-Fischer M, Blacher E, Tatirovsky E, Ben-Dov IZ, Elinav E. The gut microbiome and hypertension. Curr Opin Nephrol Hypertens. 2017;26(1):1-8. https://doi.org/10.1097/MNH. 0000000000000293.

63.• Li J, Zhao F, Wang Y, Chen J, Tao J, Tian G, et al. Gut microbiota dysbiosis contributes to the development of hypertension. Microbiome. 2017;5(1):14. https://doi.org/10.1186/s40168-0160222-x This was one of the first studies to use comprehensive metagenomic and metabolomic analyses to correlate gut microbiota dysbiosis in hypertension patients. Another highlight is fecal microbiota transfer from a hypertensive patient recapitulated high blood pressure in germ-free animals.

64.• Whelton PK, Carey RM, Aronow WS, Casey DE Jr, Collins KJ, Dennison Himmelfarb C, et al. 2017 ACC/AHA/AAPA/ABC/ $\mathrm{ACPM} / \mathrm{AGS} / \mathrm{APhA} / \mathrm{ASH} / \mathrm{ASPC} / \mathrm{NMA} / \mathrm{PCNA}$ guideline for the prevention, detection, evaluation, and management of high blood pressure in adults: a report of the American College of Cardiology/ American Heart Association Task Force on Clinical Practice Guidelines. Hypertension. 2018;71(6):e13-e115. https://doi.org/ 10.1161/HYP.0000000000000065 This was the most recent hypertension prevention and management guideline from the American College of Cardiology and American Heart Association. Highlights included genetic and environmental risk factors, in addition to potential treatment plans.

65. Landecker H. Food as exposure: Nutritional epigenetics and the new metabolism. Biosocieties. 2011;6(2):167-94. https://doi.org/ 10.1057/biosoc.2011.1.

66. Sun J, Buys NJ, Hills AP. Dietary pattern and its association with the prevalence of obesity, hypertension and other cardiovascular risk factors among Chinese older adults. Int J Environ Res Public Health. 2014;11(4):3956-71. https://doi.org/10.3390/ ijerph110403956.

67. Nguyen S, Choi HK, Lustig RH, Hsu CY. Sugar-sweetened beverages, serum uric acid, and blood pressure in adolescents. J Pediatr. 2009;154(6):807-13. https://doi.org/10.1016/j.jpeds. 2009.01.015.

68. Perez-Pozo SE, Schold J, Nakagawa T, Sanchez-Lozada LG, Johnson RJ, Lillo JL. Excessive fructose intake induces the features of metabolic syndrome in healthy adult men: role of uric acid in the hypertensive response. Int J Obes. 2010;34(3):454-61. https://doi.org/10.1038/ijo.2009.259.

69. Brown CM, Dulloo AG, Yepuri G, Montani JP. Fructose ingestion acutely elevates blood pressure in healthy young humans. Am J Phys Regul Integr Comp Phys. 2008;294(3):R730-7. https://doi. org/10.1152/ajpregu.00680.2007.

70. Jalal DI, Smits G, Johnson RJ, Chonchol M. Increased fructose associates with elevated blood pressure. J Am Soc Nephrol. 2010;21(9):1543-9. https://doi.org/10.1681/ASN.2009111111.
71. Klein AV, Kiat $\mathrm{H}$. The mechanisms underlying fructose-induced hypertension: a review. J Hypertens. 2015;33(5):912-20. https:// doi.org/10.1097/HJH.0000000000000551.

72. Singh AK, Amlal H, Haas PJ, Dringenberg U, Fussell S, Barone SL, et al. Fructose-induced hypertension: essential role of chloride and fructose absorbing transporters PAT1 and Glut5. Kidney Int. 2008;74(4):438-47. https://doi.org/10.1038/ki.2008.184.

73. Wang H, Meng QH, Chang T, Wu L. Fructose-induced peroxynitrite production is mediated by methylglyoxal in vascular smooth muscle cells. Life Sci. 2006;79(26):2448-54. https://doi. org/10.1016/j.lfs.2006.08.009.

74. Song J, Hu X, Shi M, Knepper MA, Ecelbarger CA. Effects of dietary fat, $\mathrm{NaCl}$, and fructose on renal sodium and water transporter abundances and systemic blood pressure. Am J Physiol Ren Physiol. 2004;287(6):F1204-12. https://doi.org/10.1152/ajprenal. 00063.2004.

75.•• Sud N, Zhang H, Pan K, Cheng X, Cui J, Su Q. Aberrant expression of microRNA induced by high-fructose diet: implications in the pathogenesis of hyperlipidemia and hepatic insulin resistance. J Nutr Biochem. 2017;43:125-31. https://doi.org/10.1016/j. jnutbio.2017.02.003 This was the only study to have analyzed the microRNA profile following a high fructose diet. As fructose is a known hypertensive agent, this opens an uncharted axis of fructose-microRNA-hypertension.

76. Nemecz M, Alexandru N, Tanko G, Georgescu A. Role of MicroRNA in endothelial dysfunction and hypertension. Curr Hypertens Rep. 2016;18(12):87. https://doi.org/10.1007/s11906016-0696-8.

77. Motta V, Favero C, Dioni L, Iodice S, Battaglia C, Angelici L, et al. MicroRNAs are associated with blood-pressure effects of exposure to particulate matter: results from a mediated moderation analysis. Environ Res. 2016;146:274-81. https://doi.org/10.1016/ j.envres.2016.01.010.

78. Wang Y, Jin L. miRNA-145 is associated with spontaneous hypertension by targeting SLC7A1. Exp Ther Med. 2018;15(1): 548-52. https://doi.org/10.3892/etm.2017.5371.

79. Fountain JH, Lappin SL. Physiology, renin angiotensin system. Treasure Island: StatPearls; 2020.

80. Yokota R, Ronchi FA, Fernandes FB, Jara ZP, Rosa RM, Leite $\mathrm{APO}$, et al. Intra-renal angiotensin levels are increased in highfructose fed rats in the extracorporeal renal perfusion model. Front Physiol. 2018;9:1433. https://doi.org/10.3389/fphys.2018.01433.

81. Giacchetti G, Sechi LA, Griffin CA, Don BR, Mantero F, Schambelan M. The tissue renin-angiotensin system in rats with fructose-induced hypertension: overexpression of type 1 angiotensin II receptor in adipose tissue. J Hypertens. 2000;18(6): 695-702. https://doi.org/10.1097/00004872-200018060-00006.

82.• Yang Y, Zhou Y, Cao Z, Tong XZ, Xie HQ, Luo T, et al. miR155 functions downstream of angiotensin II receptor subtype 1 and calcineurin to regulate cardiac hypertrophy. Exp Ther Med. 2016;12(3):1556-62. https://doi.org/10.3892/etm.2016.3506 This study was one of the first to describe a direct connection between the renin-angiotensin-aldosterone system and microRNAs. Implicated miR-155 as part of a negative feedback system to suppress angiotensin II receptor signaling and thus improve cardiac hypertrophy.

83. Uribarri J, Woodruff S, Goodman S, Cai W, Chen X, Pyzik R, et al. Advanced glycation end products in foods and a practical guide to their reduction in the diet. J Am Diet Assoc. 2010;110(6): 911-6 e12. https://doi.org/10.1016/j.jada.2010.03.018.

84. Schalkwijk CG, Stehouwer CD, van Hinsbergh VW. Fructosemediated non-enzymatic glycation: sweet coupling or bad modification. Diabetes Metab Res Rev. 2004;20(5):369-82. https://doi. org/10.1002/dmrr.488.

85. Mirmiran P, Yousefi R, Mottaghi A, Azizi F. Advanced glycation end products and risk of hypertension in Iranian adults: Tehran 
lipid and glucose study. J Res Med Sci. 2018;23:43. https://doi. org/10.4103/jrms.JRMS_982 17.

86. Stirban A, Gawlowski T, Roden M. Vascular effects of advanced glycation endproducts: clinical effects and molecular mechanisms. Mol Metab. 2014;3(2):94-108. https://doi.org/10.1016/j.molmet. 2013.11.006.

87. Wu XD, Liu WL, Zeng K, Lei HY, Zhang QG, Zhou SQ, et al. Advanced glycation end products activate the miRNA/RhoA/ ROCK2 pathway in endothelial cells. Microcirculation. 2014;21(2):178-86. https://doi.org/10.1111/micc.12104.

88. Lingelbach LB, Mitchell AE, Rucker RB, McDonald RB. Accumulation of advanced glycation endproducts in aging male Fischer 344 rats during long-term feeding of various dietary carbohydrates. J Nutr. 2000;130(5):1247-55. https://doi.org/10. 1093/jn/130.5.1247.

89. Gliemann L, Rytter N, Lindskrog M, Slingsby MHL, Akerstrom $\mathrm{T}$, Sylow L, et al. Endothelial mechanotransduction proteins and vascular function are altered by dietary sucrose supplementation in healthy young male subjects. J Physiol. 2017;595(16):5557-71. https://doi.org/10.1113/JP274623.

90. Brianza-Padilla M, Carbo R, Arana JC, Vazquez-Palacios G, Ballinas-Verdugo MA, Cardoso-Saldana GC, et al. Inflammation related MicroRNAs are modulated in total plasma and in extracellular vesicles from rats with chronic ingestion of sucrose. Biomed Res Int. 2016;2016:2489479-7. https://doi.org/ 10.1155/2016/2489479.

91. Li H, Zhang X, Wang F, Zhou L, Yin Z, Fan J, et al. MicroRNA21 lowers blood pressure in spontaneous hypertensive rats by upregulating mitochondrial translation. Circulation. 2016;134(10):734-51. https://doi.org/10.1161/ CIRCULATIONAHA.116.023926 This study found that specific microRNAs can have a positive effect on mitochondrial translation, which can reduce bloood pressure in spontaneously hypertensive rats.

92. Shi L, Fisslthaler B, Zippel N, Fromel T, Hu J, Elgheznawy A, et al. MicroRNA-223 antagonizes angiogenesis by targeting beta1 integrin and preventing growth factor signaling in endothelial cells. Circ Res. 2013;113(12):1320-30. https://doi.org/10.1161/ CIRCRESAHA.113.301824.

93. Ozemek C, Laddu DR, Arena R, Lavie CJ. The role of diet for prevention and management of hypertension. Curr Opin Cardiol. 2018;33(4):388-93. https://doi.org/10.1097/HCO. 0000000000000532 .

94. Taylor LE, Gillis EE, Musall JB, Baban B, Sullivan JC. High-fat diet-induced hypertension is associated with a proinflammatory $\mathrm{T}$ cell profile in male and female Dahl salt-sensitive rats. Am J Physiol Heart Circ Physiol. 2018;315(6):H1713-H23. https:// doi.org/10.1152/ajpheart.00389.2018.

95. Hsu CN, Hou CY, Chan JYH, Lee CT, Tain YL. Hypertension programmed by perinatal high-fat diet: effect of maternal gut microbiota-targeted therapy. Nutrients. 2019;11(12). https://doi. org/10.3390/nu11122908.

96.•• Siddeek B, Mauduit C, Chehade H, Blin G, Liand M, Chindamo $\mathrm{M}$, et al. Long-term impact of maternal high-fat diet on offspring cardiac health: role of micro-RNA biogenesis. Cell Death Discov. 2019;5:71. https://doi.org/10.1038/s41420-019-0153-y This was one of the first studies to link microRNA synthesis as part of the mechanism for cardiac alterations from early developmental exposure to nutritional imbalance.

97. Mantilla-Escalante DC, Lopez de Las Hazas MC, Gil-Zamorano J, Del Pozo-Acebo L, Crespo MC, Martin-Hernandez R, et al. Postprandial circulating miRNAs in response to a dietary fat challenge. Nutrients. 2019;11(6). https://doi.org/10.3390/nu11061326 This study revealed the dynamic changes of microRNA signatures postprandial from dietary fat ingestion.
98. Alexandru N, Constantin A, Nemecz M, Comarita IK, Vilcu A, Procopciuc A, et al. Hypertension associated with hyperlipidemia induced different MicroRNA expression profiles in plasma, platelets, and platelet-derived microvesicles; effects of endothelial progenitor cell therapy. Front Med (Lausanne). 2019;6:280. https:// doi.org/10.3389/fmed.2019.00280.

99. Li T, Yang GM, Zhu Y, Wu Y, Chen XY, Lan D, et al. Diabetes and hyperlipidemia induce dysfunction of VSMCs: contribution of the metabolic inflammation/miRNA pathway. Am J Physiol Endocrinol Metab. 2015;308(4):E257-69. https://doi.org/10. 1152/ajpendo.00348.2014.

100.• Barbalata T, Zhang L, Dulceanu MD, Stancu CS, Devaux Y, Sima AV, et al. Regulation of microRNAs in high-fat diet induced hyperlipidemic hamsters. Sci Rep. 2020;10(1):20549. https://doi. org/10.1038/s41598-020-77539-4 This was the first study to analyze the microRNA profile in hyperlipidemia-associated hypertension. Bioinformatic analysis revealed new targets in lipid metabolism based on microRNA expressions.

101. Wang L, Manson JE, Forman JP, Gaziano JM, Buring JE, Sesso HD. Dietary fatty acids and the risk of hypertension in middleaged and older women. Hypertension. 2010;56(4):598-604. https://doi.org/10.1161/HYPERTENSIONAHA.110.154187.

102. Nazari M, Saberi A, Karandish M, Jalali MT. Adipose tissue miRNA level variation through conjugated linoleic acid supplementation in diet-induced obese rats. Adv Clin Exp Med. 2018;27(11):1477-82. https://doi.org/10.17219/acem/93728.

103. Zhang J, Zhao WS, Wang X, Xu L, Yang XC. Palmitic acid increases endothelin-1 expression in vascular endothelial cells through the induction of endoplasmic reticulum stress and protein kinase C signaling. Cardiology. 2018;140(3):133-40. https://doi. org/10.1159/000490093.

104. Ghosh A, Gao L, Thakur A, Siu PM, Lai CWK. Role of free fatty acids in endothelial dysfunction. J Biomed Sci. 2017;24(1):50. https://doi.org/10.1186/s12929-017-0357-5.

105. Lopez S, Bermudez B, Montserrat-de la Paz S, Abia R, Muriana FJG. A microRNA expression signature of the postprandial state in response to a high-saturated-fat challenge. J Nutr Biochem. 2018;57:45-55. https://doi.org/10.1016/j.jnutbio.2018.03.010.

106. Appel LJ, Brands MW, Daniels SR, Karanja N, Elmer PJ, Sacks FM, et al. Dietary approaches to prevent and treat hypertension: a scientific statement from the American Heart Association. Hypertension. 2006;47(2):296-308. https://doi.org/10.1161/01. HYP.0000202568.01167.B6.

107. Buendia JR, Bradlee ML, Singer MR, Moore LL. Diets higher in protein predict lower high blood pressure risk in Framingham Offspring Study adults. Am J Hypertens. 2015;28(3):372-9. https://doi.org/10.1093/ajh/hpu157.

108. Engberink MF, Geleijnse JM, Bakker SJ, Larsen TM, HandjievaDarlesnka T, Kafatos A, et al. Effect of a high-protein diet on maintenance of blood pressure levels achieved after initial weight loss: the DiOGenes randomized study. J Hum Hypertens. 2015;29(1):58-63. https://doi.org/10.1038/jhh.2014.30.

109. Cooke JP. Asymmetrical dimethylarginine: the Uber marker? Circulation. 2004;109(15):1813-8. https://doi.org/10.1161/01. CIR.0000126823.07732.D5.

110. Ditscheid B, Funfstuck R, Busch M, Schubert R, Gerth J, Jahreis G. Effect of L-methionine supplementation on plasma homocysteine and other free amino acids: a placebo-controlled doubleblind cross-over study. Eur J Clin Nutr. 2005;59(6):768-75. https://doi.org/10.1038/sj.ejcn.1602138.

111. Yang B, Fan S, Zhi X, He J, Ma P, Yu L, et al. Interactions of homocysteine and conventional predisposing factors on hypertension in Chinese adults. J Clin Hypertens (Greenwich). 2017;19(11):1162-70. https://doi.org/10.1111/jch.13075.

112. Zhong F, Zhuang L, Wang Y, Ma Y. Homocysteine levels and risk of essential hypertension: a meta-analysis of published 
epidemiological studies. Clin Exp Hypertens. 2017;39(2):160-7. https://doi.org/10.1080/10641963.2016.1226888.

113. Perticone F, Sciacqua A, Maio R, Perticone M, Maas R, Boger $\mathrm{RH}$, et al. Asymmetric dimethylarginine, L-arginine, and endothelial dysfunction in essential hypertension. J Am Coll Cardiol. 2005;46(3):518-23. https://doi.org/10.1016/j.jacc.2005.04.040.

114.• Li T, Yu B, Liu Z, Li J, Ma M, Wang Y, et al. Homocysteine directly interacts and activates the angiotensin II type I receptor to aggravate vascular injury. Nat Commun. 2018;9(1):11. https://doi. org/10.1038/s41467-017-02401-7 This was the first study to find that homocysteine is involved in the renin-angiotensinaldosterone system and provides mechanistic insight into how homocysteine promotes hypertension.

115. Rodrigo R, Passalacqua W, Araya J, Orellana M, Rivera G. Implications of oxidative stress and homocysteine in the pathophysiology of essential hypertension. J Cardiovasc Pharmacol. 2003;42(4):453-61. https://doi.org/10.1097/00005344200310000-00001.

116. Zhang HP, Wang YH, Cao CJ, Yang XM, Ma SC, Han XB, et al. A regulatory circuit involving miR-143 and DNMT3a mediates vascular smooth muscle cell proliferation induced by homocysteine. Mol Med Rep. 2016;13(1):483-90. https://doi.org/10.3892/ mmr.2015.4558.

117. Li Y, Chen F, Guo R, Jia S, Li W, Zhang B. Tanshinone A inhibits homocysteine-induced proliferation of vascular smooth muscle cells via miR-145/CD40 signaling. Biochem Biophys Res Commun. 2020;522(1):157-63. https://doi.org/10.1016/j.bbrc. 2019.11.055.

118. Guo X, Li D, Chen M, Chen L, Zhang B, Wu T, et al. miRNA-145 inhibits VSMC proliferation by targeting CD40. Sci Rep. 2016;6: 35302. https://doi.org/10.1038/srep35302.

119. Duan H, Li Y, Yan L, Yang H, Wu J, Qian P, et al. MicroRNA217 suppresses homocysteine-induced proliferation and migration of vascular smooth muscle cells via N-methyl-D-aspartic acid receptor inhibition. Clin Exp Pharmacol Physiol. 2016;43(10):96775. https://doi.org/10.1111/1440-1681.12611.

120. Menghini R, Casagrande V, Cardellini M, Martelli E, Terrinoni A, Amati F, et al. MicroRNA 217 modulates endothelial cell senescence via silent information regulator 1. Circulation. 2009;120(15):1524 32. https://doi.org/10.1161/CIRCULATIONAHA.109.864629.

121.• Zhang M, Li F, Wang X, Gong J, Xian Y, Wang G, et al. MiR145 alleviates Hcy-induced VSMC proliferation, migration, and phenotypic switch through repression of the PI3K/Akt/mTOR pathway. Histochem Cell Biol. 2020;153(5):357-66. https://doi. org/10.1007/s00418-020-01847-z This was one of the most recent studies that investigated the interaction between microRNAs and homocysteine. Found that miR-145 is beneficial in abating homocysteine-induced proliferation, which could be applied to hypertension.

122. Mishra PK, Tyagi N, Kundu S, Tyagi SC. MicroRNAs are involved in homocysteine-induced cardiac remodeling. Cell Biochem Biophys. 2009;55(3):153-62. https://doi.org/10.1007/ s12013-009-9063-6.

123. Dakshinamurti K, Dakshinamurti S. Blood pressure regulation and micronutrients. Nutr Res Rev. 2001;14(1):3-44. https://doi. org/10.1079/NRR200116.

124. Garfinkle MA. Salt and essential hypertension: pathophysiology and implications for treatment. J Am Soc Hypertens. 2017;11(6): 385-91. https://doi.org/10.1016/j.jash.2017.04.006.

125. Rucker AJ, Rudemiller NP, Crowley SD. Salt, hypertension, and immunity. Annu Rev Physiol. 2018;80:283-307. https://doi.org/ 10.1146/annurev-physiol-021317-121134.

126. Ueda K, Nishimoto M, Hirohama D, Ayuzawa N, Kawarazaki W, Watanabe A, et al. Renal dysfunction induced by kidney-specific gene deletion of Hsd11b2 as a primary cause of salt-dependent hypertension. Hypertension. 2017;70(1):111-8. https://doi.org/10. 1161/HYPERTENSIONAHA.116.08966.

127. Bier A, Braun T, Khasbab R, Di Segni A, Grossman E, Haberman Y, et al. A high salt diet modulates the gut microbiota and short chain fatty acids production in a salt-sensitive hypertension rat model. Nutrients. 2018;10(9). https://doi.org/10.3390/ nu10091154.

128. Rossitto G, Maiolino G, Lerco S, Ceolotto G, Blackburn G, Mary $\mathrm{S}$, et al. High sodium intake, glomerular hyperfiltration and protein catabolism in patients with essential hypertension. Cardiovasc Res. 2020. https://doi.org/10.1093/cvr/cvaa205.

129. Nomura N, Shoda W, Wang Y, Mandai S, Furusho T, Takahashi $\mathrm{D}$, et al. Role of $\mathrm{ClC}-\mathrm{K}$ and barttin in low potassium-induced sodium chloride cotransporter activation and hypertension in mouse kidney. Biosci Rep. 2018;38(1). https://doi.org/10.1042/ BSR20171243.

130. Qi H, Liu Z, Liu B, Cao H, Sun W, Yan Y, et al. micro-RNA screening and prediction model construction for diagnosis of salt-sensitive essential hypertension. Medicine (Baltimore). 2017;96(17):e6417. https://doi.org/10.1097/MD.0000000000006417.

131. Naraba H, Iwai N. Assessment of the microRNA system in saltsensitive hypertension. Hypertens Res. 2005;28(10):819-26. https://doi.org/10.1291/hypres.28.819.

132. Zhu Q, Hu J, Wang L, Wang W, Wang Z, Li PL, et al. Inhibition of microRNA-429 in the renal medulla increased salt sensitivity of blood pressure in Sprague Dawley rats. J Hypertens. 2017;35(9): 1872-80. https://doi.org/10.1097/HJH.0000000000001373.

133. Lu C, Chen B, Chen C, Li H, Wang D, Tan Y, et al. CircNrlh4 regulates the pathological process of renal injury in salt-sensitive hypertensive mice by targeting miR-155-5p. J Cell Mol Med. 2020;24(2):1700-12. https://doi.org/10.1111/jcmm.14863.

134. Liu Y, Taylor NE, Lu L, Usa K, Cowley AW Jr, Ferreri NR, et al. Renal medullary microRNAs in Dahl salt-sensitive rats: miR-29b regulates several collagens and related genes. Hypertension. $2010 ; 55(4): 974-82$. https://doi.org/10.1161/ HYPERTENSIONAHA.109.144428.

135. Ye H, Ling S, Castillo AC, Thomas B, Long B, Qian J, et al. Nebivolol induces distinct changes in profibrosis microRNA expression compared with atenolol, in salt-sensitive hypertensive rats. Hypertension. 2013;61(5):1008-13. https://doi.org/10.1161/ HYPERTENSIONAHA.111.00892.

136. Jiang SZ, Lu W, Zong XF, Ruan HY, Liu Y. Obesity and hypertension. Exp Ther Med. 2016;12(4):2395-9. https://doi.org/10. 3892/etm.2016.3667.

137. Mango VL, Frishman WH. Physiologic, psychologic, and metabolic consequences of bariatric surgery. Cardiol Rev. 2006;14(5): 232-7. https://doi.org/10.1097/01.crd.0000223656.06812.ae.

138. Arterburn DE, Courcoulas AP. Bariatric surgery for obesity and metabolic conditions in adults. BMJ. 2014;349:g3961. https://doi. org/10.1136/bmj.g3961.

139. Ortega FJ, Mercader JM, Catalan V, Moreno-Navarrete JM, Pueyo N, Sabater M, et al. Targeting the circulating microRNA signature of obesity. Clin Chem. 2013;59(5):781-92. https://doi. org/10.1373/clinchem.2012.195776.

140. Alkandari A, Ashrafian H, Sathyapalan T, Darzi A, Holmes E, Athanasiou T, et al. Bariatric surgery modulates urinary levels of MicroRNAs involved in the regulation of renal function. Front Endocrinol (Lausanne). 2019;10:319. https://doi.org/10.3389/ fendo.2019.00319.

141. Sangiao-Alvarellos S, Theofilatos K, Barwari T, Gutmann C, Takov K, Singh B, et al. Metabolic recovery after weight loss surgery is reflected in serum microRNAs. BMJ Open Diabetes Res Care. 2020;8(2). https://doi.org/10.1136/bmjdrc-2020001441.

142. Ortega FJ, Mercader JM, Moreno-Navarrete JM, Nonell L, Puigdecanet E, Rodriquez-Hermosa JI, et al. Surgery-induced 
weight loss is associated with the downregulation of genes targeted by MicroRNAs in adipose tissue. J Clin Endocrinol Metab. 2015;100(11):E1467-76. https://doi.org/10.1210/jc. 2015-2357.

143. Langi G, Szczerbinski L, Kretowski A. Meta-analysis of differential miRNA expression after bariatric surgery. J Clin Med. 2019;8(8). https://doi.org/10.3390/jcm8081220 This was the most recent meta-analysis to describe that microRNAs reflect metabolic recovery post bariatric surgery.

144. Alkandari A, Ashrafian H, Sathyapalan T, Sedman P, Darzi A, Holmes E, et al. Improved physiology and metabolic flux after Roux-en-Y gastric bypass is associated with temporal changes in the circulating microRNAome: a longitudinal study in humans. BMC Obes. 2018;5:20. https://doi.org/10.1186/s40608-0180199-z.

145. Flores L, Vidal J, Canivell S, Delgado S, Lacy A, Esmatjes E. Hypertension remission 1 year after bariatric surgery: predictive factors. Surg Obes Relat Dis. 2014;10(4):661-5. https://doi.org/ 10.1016/j.soard.2013.11.010.

146. Bostrom AE, Mwinyi J, Voisin S, Wu W, Schultes B, Zhang K, et al. Longitudinal genome-wide methylation study of Roux-en-Y gastric bypass patients reveals novel $\mathrm{CpG}$ sites associated with essential hypertension. BMC Med Genet. 2016;9:20. https://doi. org/10.1186/s12920-016-0180-y.

147. Hamer HM, De Preter V, Windey K, Verbeke K. Functional analysis of colonic bacterial metabolism: relevant to health? Am J Physiol Gastrointest Liver Physiol. 2012;302(1):G1-9. https:// doi.org/10.1152/ajpgi.00048.2011.

148. Korpela K. Diet, microbiota, and metabolic health: trade-off between saccharolytic and proteolytic fermentation. Annu Rev Food Sci Technol. 2018;9:65-84. https://doi.org/10.1146/annurevfood-030117-012830.

149. Robles-Vera I, Toral M, de la Visitacion N, Sanchez M, GomezGuzman M, Romero M, et al. Probiotics prevent dysbiosis and the rise in blood pressure in genetic hypertension: role of short-chain fatty acids. Mol Nutr Food Res. 2020;64(6):e1900616. https://doi. org/10.1002/mnfr.201900616.

150. Ganesh BP, Nelson JW, Eskew JR, Ganesan A, Ajami NJ, Petrosino JF, et al. Prebiotics, probiotics, and acetate supplementation prevent hypertension in a model of obstructive sleep apnea. Hypertension. 2018;72(5):1141-50. https://doi.org/10.1161/ HYPERTENSIONAHA.118.11695.

151. Hsu CN, Lin YJ, Hou CY, Tain YL. Maternal administration of probiotic or prebiotic prevents male adult rat offspring against developmental programming of hypertension induced by high fructose consumption in pregnancy and lactation. Nutrients. 2018;10(9). https://doi.org/10.3390/nu10091229.

152. Khalesi S, Sun J, Buys N, Jayasinghe R. Effect of probiotics on blood pressure: a systematic review and meta-analysis of randomized, controlled trials. Hypertension. 2014;64(4):897-903. https:// doi.org/10.1161/HYPERTENSIONAHA.114.03469.

153. Qi D, Nie XL, Zhang JJ. The effect of probiotics supplementation on blood pressure: a systemic review and meta-analysis. Lipids Health Dis. 2020;19(1):79. https://doi.org/10.1186/s12944-02001259-x This was the most recent meta-analysis to describe the effects of probiotics on blood pressure.

154.• Calderon-Perez L, Gosalbes MJ, Yuste S, Valls RM, Pedret A, Llaurado E, et al. Gut metagenomic and short chain fatty acids signature in hypertension: a cross-sectional study. Sci Rep. 2020;10(1):6436. https://doi.org/10.1038/s41598-020-63475-w

This was one of the most recent studies to connect a depletion of circulating short chain fatty acids in hypertension patients. Identified a hypertension classifier based on the microbiota and bacterial metabolites.

155. Huart J, Leenders J, Taminiau B, Descy J, Saint-Remy A, Daube G, et al. Gut microbiota and fecal levels of short-chain fatty acids differ upon 24-hour blood pressure levels in men. Hypertension. 2019;74(4):1005-13. https://doi.org/10.1161/ HYPERTENSIONAHA.118.12588.

156. de la Cuesta-Zuluaga J, Mueller NT, Alvarez-Quintero R, Velasquez-Mejia EP, Sierra JA, Corrales-Agudelo V, et al. Higher fecal short-chain fatty acid levels are associated with gut microbiome dysbiosis, obesity, hypertension and cardiometabolic disease risk factors. Nutrients. 2018;11(1). https://doi.org/10. 3390/nu11010051.

157. Pluznick JL. Microbial short-chain fatty acids and blood pressure regulation. Curr Hypertens Rep. 2017;19(4):25. https://doi.org/10. 1007/s11906-017-0722-5.

158. Pluznick JL. Gut microbiota in renal physiology: focus on shortchain fatty acids and their receptors. Kidney Int. 2016;90(6): 1191-8. https://doi.org/10.1016/j.kint.2016.06.033.

159. Natarajan N, Hori D, Flavahan S, Steppan J, Flavahan NA, Berkowitz DE, et al. Microbial short chain fatty acid metabolites lower blood pressure via endothelial $G$ protein-coupled receptor 41. Physiol Genomics. 2016;48(11):826-34. https://doi.org/10. 1152/physiolgenomics.00089.2016.

160. Pluznick JL, Protzko RJ, Gevorgyan H, Peterlin Z, Sipos A, Han J, et al. Olfactory receptor responding to gut microbiota-derived signals plays a role in renin secretion and blood pressure regulation. Proc Natl Acad Sci U S A. 2013;110(11):4410-5. https://doi.org/ 10.1073/pnas.1215927110.

161. Zhang L, Deng M, Lu A, Chen Y, Chen Y, Wu C, et al. Sodium butyrate attenuates angiotensin II-induced cardiac hypertrophy by inhibiting COX2/PGE2 pathway via a HDAC5/HDAC6dependent mechanism. J Cell Mol Med. 2019;23(12):8139-50. https://doi.org/10.1111/jcmm.14684.

162. Weber GJ, Foster J, Pushpakumar SB, Sen U. Altered microRNA regulation of short chain fatty acid receptors in the hypertensive kidney is normalized with hydrogen sulfide supplementation. Pharmacol Res. 2018;134:157-65. https://doi.org/10.1016/j.phrs. 2018.06.012

163. Teng Y, Ren Y, Sayed M, Hu X, Lei C, Kumar A, et al. Plantderived exosomal MicroRNAs shape the gut microbiota. Cell Host Microbe. 2018;24(5):637-52 e8. https://doi.org/10.1016/j.chom. 2018.10.001.

164. Yubero-Serrano EM, Fernandez-Gandara C, Garcia-Rios A, Rangel-Zuniga OA, Gutierrez-Mariscal FM, Torres-Pena JD, et al. Mediterranean diet and endothelial function in patients with coronary heart disease: an analysis of the CORDIOPREV randomized controlled trial. PLoS Med. 2020;17(9):e1003282. https://doi.org/10.1371/journal.pmed.1003282.

Publisher's Note Springer Nature remains neutral with regard to jurisdictional claims in published maps and institutional affiliations. 